\title{
4-Methylphthalate catabolism in Burkholderia (Pseudomonas) cepacia Pc701 : a gene encoding a phthalate-specific permease forms part of a novel gene cluster
}

\author{
Christopher P. Saint + and Pauline Romas
}

Author for correspondence: Christopher P. Saint. Tel: +61 82590378 . Fax: +61 82590228.
c-mail: chris.sainta.sawater.sa.gov.au

Department of

Microbiology, Monash

University, Clayton, Victoria

3168, Australia
We have determined the entire nucleotide sequence of a $4.4 \mathrm{kbp}$ fragment of pMOP, a plasmid involved in 4-methylphthalate catabolism in Burkholderia cepacia (formerly Pseudomonas cepacia) Pc701. Two complete ORFs were identified and termed mopA and mopB. mopB encodes a 4-methylphthalate permease which is a member of a superfamily of symport proteins found in both prokaryotes and eukaryotes. Functionality was assigned to MopB by detailed analysis of the predicted amino acid sequence, resulting in the identification of 12 hydrophobic membrane-spanning domains and motifs associated with this class of protein. An assay was developed to demonstrate MopB function in substrate uptake. Of 4-methylphthalate, 4-

hydroxyisophthalate, benzoate, p-toluate and phthalate, only uptake of 4methylphthalate and phthalate was demonstrated, suggesting that two carboxyl groups in the ortho position are essential for substrate recognition. The predicted protein MopA showed significant levels of homology to reductase proteins implicated in aromatic and aliphatic catabolism, and contained motifs recognized as binding the ADP and flavin moieties of FAD/NAD. Northern hybridization experiments determined that mopA and mopB are cotranscribed, but expression was only seen in cells grown on 4methylphthalate and not in cells grown on closely related structural analogues, including phthalate. mopA and mopB may be situated at the $3^{\prime}$ terminus of a cistron about $10 \mathrm{kbp}$ in size. The isolation and characterization of a 4-methylphthalate permease gene may lead to the identification of other permeases involved in bacterial biodegradation processes and possibly the construction of strains with enhanced degradative abilities.

Keywords: Burkbolderia (Pseudomonas), phthalates, gene organization, phthalate-specific permease

\section{INTRODUCTION}

Phthalate wastes are discharged into the environment by the plastics, paper and paint industries. Phthalates can accumulate at air-water interfaces and reach toxic levels in the tissues of animals that feed at such interfaces, and so

\footnotetext{
†Present address: The Cooperative Research Centre for Water Quality and Treatment, Australian Water Quality Centre, Bolivar, SA5108, Australia.

Abbreviations: DIG, digoxigenin; MCS, multiple cloning site.

The GenBank accession number for the sequence reported in this paper is U29532.
}

their presence in the environment is of some concern (Autian, 1973; Peakall, 1975; Keith \& Telliatd, 1979). Studies on the genetics and biochemistry of phthalate degradation by micro-organisms may result in improved biodegtadation of industrial wastes prior to environmental release and the conversion of such wastes to useful intermediates for the organic synthetic chemicals industry.

Aerobic phthalate degradation appears to proceed via phthalate dioxygenase, consisting of phthalate oxygenase and phthalate oxygenase reductase, and a dehydrogenase, yielding 4,5-dihydroxyphthalate in Pseudomonas fiuorescens (Pujar \& Ribbons, 1985), Pseudomonas testosteroni (Naka- 
zawa \& Hayashi, 1977) and Comamonas acidovorans (Dutton et al., 1995), or 3,4-dihydroxyphthalate in Micrococcus sp. (Eaton \& Ribbons, 1982). The products are subsequently decarboxylated to yield protocatechuate, which is further converted to amphibolic intermediates via an ortbocleavage pathway. Anderson (1980) isolated a soil pseudomonad capable of the degradation of 4-methylphthalate, 4-hydroxyisophthalate and phthalate. Through enzyme assays and analysis of mutants which accumulated pathway intermediates, a tentative pathway for 4-methylphthalate degradation was proposed (Anderson, 1980; Saint, 1986). A 4-methylphthalate 2,3-dioxygenase followed by a dehydrogenase convert the substrate to $2,3-$ dihydroxy-p-toluate, which is subsequently subjected to meta-cleavage at the 3,4 position. The ring cleavage product is then decarboxylated and converted to tricarboxylic acid cycle intermediates. The ability to utilize 4-methylphthalate (Mop) was unstable and Mop ${ }^{-}$derivatives were also found to have lost the ability to utilize 4hydroxyisophthalate (Hip) but retained the ability to grow on phthalate.

Subsequently the ability to utilize 4-methylphthalate and 4-hydroxyisophthalate was demonstrated to be plasmidencoded (Saint \& Ribbons, 1990). The plasmid was sized at between 226 and $232 \mathrm{kbp}$ and $\mathrm{Mop}^{+}$and $\mathrm{Hip}^{+}$ phenotypes could be reintroduced to an isogenic cured $\left(\mathrm{pMOP}^{-}\right)$derivative of the wild-type isolate Burkbolderia cepacia Pc701. Transposon mutagenesis with Tn1 produced a Mop ${ }^{-} \mathrm{Hip}^{+}$derivative of B. cepacia Pc701, termed B. cepacia Pc704. It was confirmed that 'Tn1 had inserted into a $2 \cdot 1 \mathrm{kbp}$ HindIII-derived fragment of $\mathrm{pMOP}$ in this isolate. A partial HindIII digestion of pMOP was performed and the resultant fragments were cloned into pKT230. One recombinant, pCS1 (pMOP1000), was able to restore a Mop ${ }^{+}$phenotype to $B$. cepacia Pc704 by complementation, and was found to contain two contiguous HindIII fragments of 2.3 and $2.1 \mathrm{kbp}$ derived from pMOP. This was the first report of genes involved in the catabolism of phthalates being plasmid-encoded, although subsequently Nomura et al. (1990) and Dutton et al. (1995) have described large plasmids involved in phthalate catabolism in Pseudomonas putida and C. acidovorans, respectively.

In this paper, we report the entire nucleotide sequence of a $\mathrm{pMOP}$-derived $4.4 \mathrm{kbp}$ insert in pMOP1000. We present evidence that the region involved in complementation encodes a 4-methylphthalate/phthalate-specific permease and identify an ORF upstream which may encode a 4methylphthalate reductase. To our knowledge, this is the first molecular and functional demonstration of a permease involved in aromatic uptake as a prelude to catabolism.

\section{METHODS}

Bacterial strains and plasmids. The Burkbolderia cepacia and Escherichia coli strains and the plasmids used and constructed during the course of this study are detailed in Table 1.

Chemicals and enzymes. All chemicals were of analytical grade and purchased from BDH, Sigma or Boehringer Mannheim unless otherwise indicated. Restriction endonucleases and other DNA- and RNA-modifying enzymes and kits were purchased from Boehringer Mannheim unless otherwise indicated.

Media and culture conditions. L agar and L broth were prepared according to Sambrook et al. (1989). For growth of $B$. cepacia strains, solid and liquid minimal media were prepared according to Faton \& Ribbons (1982) and carbon sources were added to a final concentration of $5 \mathrm{mM}$ from a $500 \mathrm{mM}$ sterile stock solution. E. coli hosts containing plasmid clones were maintained on $\mathrm{L}$ agar containing ampicillin $\left(100 \mu \mathrm{g} \mathrm{m}^{-1}\right)$ for derivatives of $\mathrm{pKK} 233-3$ and $\mathrm{pUC18}$, and $\mathrm{L}$ agar containing streptomycin $\left(25 \mu \mathrm{g} \mathrm{ml}^{-1}\right)$ or kanamycin $\left(20 \mu \mathrm{g} \mathrm{ml}^{-1}\right)$ for pKT230 derivatives. Where pRK311 was used for cloning, E. coil recombinants were maintained on $\mathrm{L}$ agar containing tetracycline $\left(10 \mu \mathrm{g} \mathrm{ml} \mathrm{m}^{-1}\right)$.

Complementation studies. Bacterial conjugations were carried out as previously described (Saint et al., 1990). E. coli recombinants containing either pMOP1210 or pMOP1211 were transformed with pMOP1100 or pMOP1101 using standard techniques (Sambrook et al., 1989). Transformants were selected on LB agar incorporating $25 \mu \mathrm{g}$ streptomycin $\mathrm{ml}^{-1}$. Colonies were subsequently tested for retention of either PMOP1210 or pMOP1211 by growth on LB agar containing $10 \mu \mathrm{g}$ tetracycline $\mathrm{ml}^{-1}$. Transformants containing one of these two plasmids and pMOP1100 or pMOP1101 were used in triparental filter matings with E. coli(pRK2013) and B. cepacia Pc704. pRK2013 provides mobilization functions which permit transfer of the recombinant plasmids into B. cepacia Pc704. Selection for transconjugants was made on minimal medium containing 4-methylphthalate. Other complementation studies involving pMOP1300, pMOP1400 and pMOP1730 were carried out using similat methods; however, E. coli DH $5 \alpha(\mathrm{pNJ} 5000)$ was used in place of DH5 $\alpha$ (pRK2013) to provide mobilization functions. Transfer of pMOP1000 from E. coli DH5 5 to B. cepacia Pc704 was employed as a positive control in all of these experiments.

Plasmid DNA extraction and manipulation. Plasmid DNA for restriction enzyme analysis and subcioning was extracted from $E$. coli hosts by the alkaline lysis procedure described by Sambrook et al. (1989), with the addition of the phenol/ chloroform extraction step. In addition, where DNA was to be used for cloning procedures, a final RNase treatment was employed. RNase stock $\left(10 \mathrm{mg} \mathrm{ml}^{-1}\right.$ ) (in $10 \mathrm{mM}$ Tris $/ \mathrm{HCl}$, $1 \mathrm{mM}$ EDTA, $\mathrm{pH} 8$ ) was added to a final concentration of $1 \mu \mathrm{g} \mathrm{ml} l^{-1}$ and the sample was incubated at $37^{\circ} \mathrm{C}$ for $20 \mathrm{~min}$. Restriction endonuclease digestion, treatment with calf intestinal phosphatase and ligation with $\mathrm{T} 4$ ligase were all performed in the buffer provided under the conditions specified by the manufacturer. On occasion, DNA fragments were gelpurified and extracted using Geneclean (Biolab 101) following the manufacturer's protocol

pMOP1430 was constructed using the following protocol. pKK233-3 contains two BamHI sites; one is upstream of $P_{t a c}$ and the other is within the multiple cloning site (MCS). pKK233-3 was partially digested with BamHI, and singly cut vector gel purified and recovered using Geneclean. The recovered DNA was then digested to completion with EcoRI, purified and ligated to a $3.5 \mathrm{kbp}$ BamHI-EcoRI fragment of pMOP1420, which included mopB. Ligation into the MCS downstream of $\mathrm{P}_{t a c}$ was confirmed by digestion with $S_{a l}$ pMOP1430 yields a $1 \mathrm{kbp}$ fragment when digested with $S a l$.

DNA-RNA hybridization. B. cepacia Pc701 was grown on minimal medium containing $0.05 \%(\mathrm{w} / \mathrm{v})$ Casamino acids and the appropriate carbon source at $5 \mathrm{mM}$ concentration. A $5 \mathrm{ml}$ starter culture was inoculated and grown overnight at $37^{\circ} \mathrm{C}$ with shaking. This culture $(2 \mathrm{ml})$ was used to inoculate $200 \mathrm{ml}$ 
Table 1. Bacterial strains and plasmids

\begin{tabular}{|c|c|c|}
\hline Strain or plasmid & Description & Source/reference \\
\hline \multicolumn{3}{|l|}{ Strains } \\
\hline \multicolumn{3}{|l|}{ Escherichia coli } \\
\hline JM105 & $\begin{array}{l}\text { thi rpsL end } A \text { sbcB15 asd } 4 \text { supE } \Delta \text { lac-pro } A B \mathrm{~F}^{+} \text {(traD36 } \\
\left.\text { pro } A B^{+} \text {lac } T^{\mathrm{q}} \text { lacZ } \Delta \mathrm{M} 15\right)\end{array}$ & Yanisch-Perron et al. (1985) \\
\hline $\mathrm{DH} 5 \alpha$ & 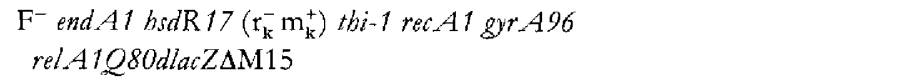 & Bethesda Research Laboratories \\
\hline \multicolumn{3}{|c|}{ Burkholderia cepacia } \\
\hline Pc701 & $\mathrm{Mop}^{+} \mathrm{Hip}^{+}, \mathrm{pMOP}$ & Saint \& Ribbons (1990) \\
\hline Pc704 & $\mathrm{Mop}^{-} \mathrm{Hip}^{+}$, pMOP: $: \operatorname{Tn} 1\left(\mathrm{Ap}^{\mathrm{K}}\right)$ & Saint \& Ribbons $(1990)$ \\
\hline \multicolumn{3}{|l|}{ Plasmids } \\
\hline pRK2013 & RK2 derivative, $\mathrm{Km}^{\mathrm{R}}$ Mob Tra & Figurski \& Helinski (1979) \\
\hline $\mathrm{pN} J 5000$ & RP4 derivative, $\mathrm{Tc}^{\mathrm{R}}$ Mob Tra & Grinter (1983) \\
\hline $\mathrm{pKT} 230$ & $\mathrm{Km}^{\mathrm{R}} \mathrm{Sm}^{\mathrm{R}}$ & Bagdasarian et al. (1981) \\
\hline pRK311 & $\mathrm{Tc}^{\mathrm{R}} \operatorname{lac} Z \cos$ & Ditta et al. (1985) \\
\hline pWSk29 & $A p^{\mathrm{R}}$ lac $Z$ & Wang \& Kushner (1991) \\
\hline pKK $233-3$ & $\mathrm{Ap}^{\mathrm{R}} \mathrm{P}_{t a t}$ & Brosius \& Holy (1984) \\
\hline pUC18 & $A p^{R} \operatorname{lac} Z$ & Yanisch-Perron et al. (1985) \\
\hline pMOP1000 & $\begin{array}{l}2.3 \text { and } 2 \cdot 1 \mathrm{kbp} \text { HindIII pMOP fragments in } \mathrm{pKT} 230, \mathrm{Sm}^{\mathrm{r}} \mathrm{Km}^{\mathrm{s}} \text {, } \\
\text { formerly pCS } 1\end{array}$ & Saint \& Ribbons (1990) \\
\hline pMOP1100 & $\begin{array}{l}2 \cdot 3 \mathrm{kbp} H i n d I I l \text { fragment from pMOP } 1000 \text { in pKT230, } \\
\mathrm{Sm}^{\mathrm{R}} \mathrm{Km}^{\mathrm{S}} \text {, formerly pCS4 }\end{array}$ & \multirow{13}{*}{ This study } \\
\hline pMOP1101 & $\begin{array}{l}\text { pMOP } 1100 \text { insert in reverse orientation in } \mathrm{pKT} 230, \mathrm{Sm}^{\mathrm{r}} \mathrm{Km}^{\mathrm{s}} \text {, } \\
\text { formerly pCS5 }\end{array}$ & \\
\hline pMOP1210 & $2 \cdot 1 \mathrm{kbp}$ HindIII fragment from pMOP1000 in pRK311, $\mathrm{Tc}^{\mathrm{R}}$ & \\
\hline pMOP1211 & pMOP1210 insert in reverse orientation in $\mathrm{pRK}^{2} 311, \mathrm{Tc}^{\mathrm{R}}$ & \\
\hline PMOP1300 & $3.3 \mathrm{kbp} X \mathrm{XoI}_{\mathrm{I}}$ fragment from $\mathrm{pMOP} 1000$ in $\mathrm{pKT} 230, \mathrm{Km}^{\mathrm{s}} \mathrm{Sm}^{\mathrm{R}}$ & \\
\hline pMOP1400 & $4.85 \mathrm{kbp}$ EcoRI fragment from $\mathrm{pMOP} 1000$ in $\mathrm{pKT} 230, \mathrm{Sm}^{\mathrm{s}} \mathrm{Km}^{\mathrm{k}}$ & \\
\hline pMOP1800 & $1.2 \mathrm{kbp}$ EcoRI-XboI fragment of pMOP1000 in pWSK29, Ap ${ }^{\mathrm{R}}$ & \\
\hline pMOP1730 & $1.2 \mathrm{kbp} X h o \mathrm{I}-S_{m a \mathrm{I}}$ fragment from pMOP1800 in $\mathrm{pKT} 230, \mathrm{Km}^{\mathrm{s}} \mathrm{Sm}^{\mathrm{R}}$ & \\
\hline pMOP1120 & $2 \cdot 3 \mathrm{kbp}$ HindIII fragment of pMOP1000 in pUC18, $\mathrm{Ap}^{\mathrm{R}}$ & \\
\hline pMOP1220 & $2 \cdot 1 \mathrm{kbp}$ HindIII fragment of pMOP1000 in pUC18, Ap ${ }^{\mathrm{R}}$ & \\
\hline pMOP1250 & $\begin{array}{l}1.2 \mathrm{kbp} X b o \mathrm{I}-E_{c o \mathrm{RI}} \text { fragment of } \mathrm{pMOP} 1000 \text { cloned thto the } \\
\text { EcoRI-Sal site of } \mathrm{pLC} 18, A \mathrm{p}^{\mathrm{R}}\end{array}$ & \\
\hline pMOP1420 & $4.85 \mathrm{kbp}$ EcoRI fragment of pMOP1000 in pUC18, $\mathrm{AP}^{\mathbf{R}}$ & \\
\hline pMOP1430 & $35 \mathrm{kbp} B a m \mathrm{HI}-E_{c o \mathrm{RI}}$ fragment of pMOP1420 in $\mathrm{pKK} 233-3, \mathrm{Ap}^{\mathrm{R}}$ & \\
\hline
\end{tabular}

medium in a $500 \mathrm{ml}$ conical flask, which was incubated with shaking at $37^{\circ} \mathrm{C}$. In initial experiments, samples were taken at early- $\left(\mathrm{OD}_{600}=0.04\right)$, mid- $\left(\mathrm{OD}_{600}=0.15\right)$ and late-exponential phase $\left(\mathrm{OD}_{600}=0 \cdot 4\right)$, rapidly cooled on ice and centrifuged at $3000 \mathrm{~g}$ for $10 \mathrm{~min}$ at $4{ }^{\circ} \mathrm{C}$. Cell pellets were resuspended in $200 \mathrm{ml} 100 \mathrm{mM}$ phosphate buffer $\left(\mathrm{pH} \mathrm{6.8)}\right.$ at $4{ }^{\circ} \mathrm{C}$ and recentrifuged. Pellets were frozen at $-70^{\circ} \mathrm{C}$ until used. For slot blot experiments, cells were routinely harvested at an $\mathrm{OD}_{609}$ of $0 \cdot 3$.

Total RNA was extracted from cell pellets using the RNeasy protocol incorporating spin column purification (Qiagen). Pellets were adjusted so that approximately $10^{9}$ cells per extraction were used. The final elution volume was $40 \mu \mathrm{l}$ diethyl pyrocarbonate (DEPC)-treated water. DNase treatment was performed by adding $1 \mu \mathrm{l}$ ( $1 \mathrm{~L})$ DNase (Promega), $1 \mu \mathrm{l}$ RNAsin (Promega), $4.7 \mu \mathrm{l} 10 \times$ DNase buffer $(100 \mathrm{mM} \mathrm{MgCl}, 200 \mathrm{mM}$ Tris $/ \mathrm{HCl}, \mathrm{pH} 8.0$ ) and incubating for $45 \mathrm{~min}$ at $37^{\circ} \mathrm{C}$. If at this stage RNA required concentration, this was achieved by ethanol precipitation and the vacuum-dried pellet was resuspended in DEPC-treated water.
For Northern transfer following gel electrophoresis of samples, RNA was electrophoresed through formaldehyde agarose gels in appropriate buffer (Sambrook et al., 1989). Hybond $\mathrm{N}^{+}$nylon membrane (Amersham) was used for all experiments. A Minifold II system (Schleicher and Schell) attached to a vacuum pump was used for slot blot analysis and the procedure of sample preparation and transfer was essentially as described by Sambrook et a/. (1989). Prehybridization and hybridization buffer consisted of $7 \%(\mathrm{w} / \mathrm{v})$ SDS, $50 \%(\mathrm{v} / \mathrm{v})$ formamide, $5 \times$ SSC ( $75 \mathrm{mM}$ sodium citrate, $750 \mathrm{mM}$ sodium chloride), $2 \%$ (w/v) blocking reagent, $0.1 \% \mathrm{~N}$-lauroylsarcosine and $0.1 \%$ $(\mathrm{v} / \mathrm{v})$ sodium phosphate, $\mathrm{pH} 7.0$.

DNA probes were prepared by PCR incorporating digoxigenin (DIG)-dU'TP. A standard reaction consisted of: $10 \mathrm{ng}$ template DNA, $18 \mu \mathrm{l} 1 \mathrm{mM}$ dNTP solution [prepared from stocks of dCTP, dATP, dGTP and dTTP $\left.\left(100 \mathrm{mmol}^{-1}\right)\right], 2 \mu \mathrm{DIG}-$ DNA labelling mixture [dATP, dCTP, dGTP $\left(0.65 \mathrm{mmol} \mathrm{l}^{-1}\right)$; $0.35 \mathrm{mmol}$ DIG-dUTP I ${ }^{-1}$ ], $10 \mu \mathrm{l} 10 \times$ PCR reaction buffer, oligonucleotide $1(100 \mu \mathrm{M})$, oligonucleotide $2(100 \mu \mathrm{M}), 1 \mathrm{U}$ Taq DNA polymerase and double glass-distilled water to $100 \mu \mathrm{l}$. 
For the internal probe to $\operatorname{mop} A$, the template was pMOP1120 and oligonucleotides were mopAF (GGCGAGATTATGATGCTCGG) position 898-917, and mop AR (TCCGGAAGGATGCTCGAACG), position 1652-1671. For the probe to $\operatorname{mop} B$, the template was pMOP1420 and oligonucleotides were mopBF (AGCTTTTGAAACCTCGCAGG), position 21972216, and mopBR (CGAAGGCGAGGCAGAGATAG), position 3463-3482. PCR was performed under the following conditions: $94^{\circ} \mathrm{C} 1 \mathrm{~min}, 55^{\circ} \mathrm{C} 1 \mathrm{~min}, 72^{\circ} \mathrm{C} 1 \mathrm{~min}, 30$ cycles; $94^{\circ} \mathrm{C} 1 \mathrm{~min}, 55^{\circ} \mathrm{C} 1 \mathrm{~min}, 72{ }^{\circ} \mathrm{C} 5 \mathrm{~min}, 1$ cycle. Reactions yielded fragments of expected size and control reactions lacking DIG-dUTP yielded identical fragments which, when analysed by restriction digestion, confirmed the correct regions had been amplified. DIG-dUTP-labelled products were electrophoresed through low-melting-point agatose and the relevant band was excised and boiled for $15 \mathrm{~min}$ before being added directly to the hybridization solution. Approximately $1 \mu \mathrm{g}$ of labelled probe was used per hybridization.

Following bybridization at $65^{\circ} \mathrm{C}$ for $16 \mathrm{~h}$, membranes were subjected to two washes in $2 \times \mathrm{SSC}, 0.1 \%(\mathrm{w} / \mathrm{v})$ SDS for $5 \mathrm{~min}$ at room temperature, followed by two washes in $0.1 \times$ SSC, $0.1 \%(\mathrm{w} / \mathrm{v}) \mathrm{SDS}$ for $15 \mathrm{~min}$ at $65^{\circ} \mathrm{C}$. Detection of hybridization was performed using a DIG chemiluminescent detection kit according to the manufacturer's protocol, using disodium 3-(4-methoxyspiro $\left\{1,2\right.$-dioxetane- $3,2^{\prime}-\left(5^{\prime}\right.$ chloro)tricyclo[3.3.1.1 $\left.1^{3,7}\right]$ decan $\left.\}-4-y l\right)$ phenyl phosphate as the substrate.

Primer extension analysis. RNA extracted from cells used in the Northern blotting experiments was also used for primer extension studies. Two oligonucleotides were designed to bind just downstream of the putative translation start codons of mopA (GATTGGTTGAGTGGTACG), position 797-814, and mopB (CTGCGAGGTTTCAAAAGC), position 21982215. End-labelling of oligonucleotides and primer extension reactions were performed using a kit according to the manufacturer's instructions (Promega). Fifty micrograms of total RNA from B. cepacia Pc701 was used in each reaction.

Aromatic uptake assays. E. coli JM105 containing pKK233-3 or PMOP1430 was grown in M9 minimal medium (Sambrook et al., 1989$)$ containing $0.05 \%(\mathrm{v} / \mathrm{v})$ Casamino acids, $10 \mu \mathrm{g}$ thiamin $\mathrm{ml}^{-1}$ and $5 \mathrm{mM}$ sodium succinate. Initially $5 \mathrm{ml}$ starter cultures were grown overnight with shaking at $37^{\circ} \mathrm{C}$. Two millilitres of culture was added to $200 \mathrm{ml}$ of fresh medium in a $500 \mathrm{ml}$ conical Hask and the culture was incubated at $37^{\circ} \mathrm{C}$ with shaking until an $\mathrm{OD}_{600}$ of 0.6 (late-exponential phase) was reached. Cells were collected by centrifugation at $3000 \mathrm{~g}$ for $10 \mathrm{~min}$, and the pellet was resuspended in $40 \mathrm{ml} \mathrm{M9} \mathrm{minimal}$ medium containing $2.5 \mathrm{mM}$ sodium succinate and the relevant aromatic substrate at a concentration of $50 \mu \mathrm{M}$.

The culture was shaken at $37^{\circ} \mathrm{C}$ for $1 \mathrm{~h}$. IPTG was then added to a final concentration of $100 \mu \mathrm{M}$. Samples $(1.5 \mathrm{ml})$ were removed at $10 \mathrm{~min}$ intervals, rapidly cooled on ice, centrifuged at $16000 \mathrm{~g}$ for $2 \mathrm{~min}$ at $4{ }^{\circ} \mathrm{C}$, and the supernatant was scanned directly between 190 and $300 \mathrm{~nm}$ using a Variant DMS 1005 model UV/visible spectrophotometer. Disappearance of aromatic substrate from the medium was revealed by a reduction in absorbance at approximately $210 \mathrm{~nm}$.

DNA sequencing. Sequencing was performed using an Applied Biosystems 373A DNA sequencer and raw data were collected using the manufacturer's software installed on a Macintosh system. DNA extraction and sequencing reactions were performed using a PRISM ready reaction DyeDeoxy terminator cycle sequencing kit, according to the manufacturer's protocol. Plasmids pMOP1120, pMOP1220 and pMOP1250 wete used to acquite sequence data. pLC18 forward (5'-TGTAAAACG-
ACGGCCAGT $-3^{\prime}$ ) and reverse (5'-CAGGAAACAGCTATGAC-3') primers were used, along with a series of 18 mers designed to 'walk' along the cloned DNA in both the forward (F) and reverse $(\mathrm{R})$ directions to complete the sequence of both strands. The coordinates of these oligonucleotides were as follows : 207-224F, 207-224R, 532-549F, 575-592R, 559-576F, 924-941F, 885-902R, 902-919R, 1198-1215F, 1242-1259R, $1548-1565 \mathrm{R}, 1815-1832 \mathrm{~F}, 1850-1867 \mathrm{R}, 1833-1850 \mathrm{~F}, 2112$ 2129F, 2139-2156F, 2262-2279R, 2550-2566F, 2897-2914F, 2901-2918R, 3192-3209R, 3198-3215R, 3206-3223F, 3613 3629F, 3614-3631R, 3980-3997F, 3980-3997R.

Computer analysis. DNA sequence contigs were constructed using Gene Jockey II (Biosoft) and screening of the sequence for secondary structure and possible promoter sequences was carried out using 'The DNA Inspector Ile program (Textco). Primers for PCR were designed using the Amplify I program (University of Wisconsin, USA). Fxamination of proteins by BLAST, Clustal V, Scrutineer (Sibbald \& Argos, 1990), the algorithm of Kyte \& Doolittle (1982), and the Alom program of Kaneshisa (1982) was performed via the Australian National Genomic Information Service (ANGIS) facility at the University of Sydney. BLAST analysis was performed at high stringency using a single-letter match score of 5 , single-letter mismatch score of -4 and word size (ktup) of 5 (Altschul $e t$ al., $1990)$.

\section{RESULTS AND DISCUSSION}

\section{Subcloning and complementation analysis}

A series of subclones containing regions within the $4.4 \mathrm{kbp}$ insert of pMOP1000 was constructed in pKT230 and pRK311 and introduced into B. cepacia Pc704 by conjugation. Fig. 1 shows these plasmids and their varying ability to restore a $\mathrm{Mop}^{+}$phenotype. We previously reported that plasmids pCS2-5, containing either the $2 \cdot 1$ or $2.3 \mathrm{kbp}$ HindIII fragment in either orientation in pKT230, could not complement B. cepacia Pc704 (Saint \& Ribbons, 1990). We cloned the $2 \cdot 1 \mathrm{kbp}$ fragment in both orientations into pRK311 to give pMOP1210 and pMOP1211. pRK311 is compatible with pKT230; therefore pMOP1210 and pMOP1211 were mobilized to $B$. cepacia Pc704 along with either PMOP1100 or PMOP1101. None of the four possible combinations resulted in complementation. This confirmed that a region spanning the central HindIII site of pMOP1000 was essential for complementation.

A $3.3 \mathrm{kbp} X b_{\circ} \mathrm{L}$ fragment of pMOP 1000 , containing the $2.3 \mathrm{kbp}$ HindIII fragment and $0.5 \mathrm{kbp}$ of the $2.1 \mathrm{kbp}$ HindIII fragment, was cloned into pKT230 to give pMOP1300 (Fig. 1). By digestion of pMOP1000 with EcoRI and ligation of the resulting $4.8 \mathrm{kbp}$ fragment into pKT230, all the $2.1 \mathrm{kbp} H$ HindIII fragment and $700 \mathrm{bp}$ of the $3^{\prime}$ region of the $2.3 \mathrm{kbp}$ HindIII fragment were cloned to give pMOP1400. A region of $1.2 \mathrm{kbp}$ bounded by EcoRI and $X h o I$ sites and encompassing the central HindIII site was cloned into PWSK29 to give pMOP1800. The MCS of pWSK29 allowed this region to be conveniently excised on a $S \mathrm{maI}-\mathrm{X} b \mathrm{I}$ fragment and subcloned into pK'T230 to give pMOP1730. Neither pMOP1300 or pMOP1730 restored a Mop ${ }^{+}$phenotype to B. cepacia Pc704, whereas pMOP1400 did. This defined the start of the complementing region, with respect to Fig. 1, 


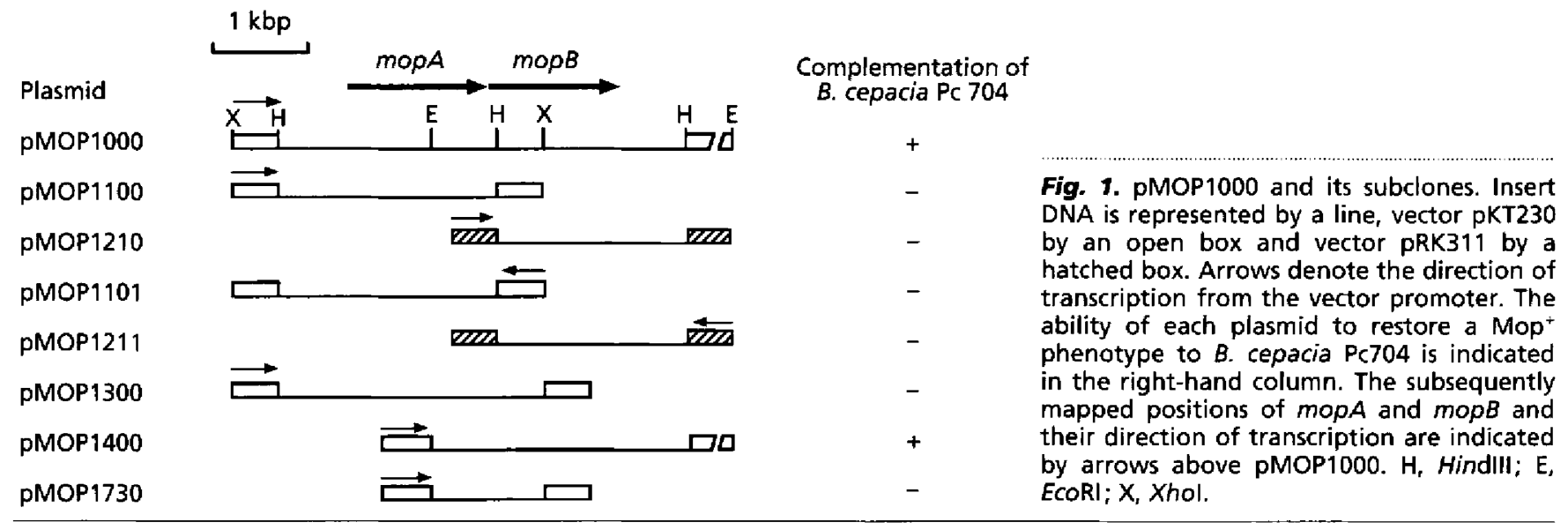

as downstream of the EcoRI site and running into the $2.1 \mathrm{kbp}$ HindIII fragment beyond the XhoI site. Both the 2.3 and $2.1 \mathrm{kbp}$ HindIII fragments and the central $1.2 \mathrm{kbp}$ EcoRI-XboI region were cloned into pUC18 to give pMOP1120, pMOP1220 and pMOP1250, respectively. Initial sequence analysis was performed on pMOP 1250 and pMOP1220, which encompass the complementing region, followed by pMOP1120, to complete the entire sequence of the original pMOP1000 insert.

\section{Identification of mopA and mopB}

Fig. 2 shows the complete nucleotide sequence of the insert in PMOP1000 derived from $\mathrm{PMOP}$. There are three predicted ORFs, which appear to be transcribed from left to right with respect to pMOP1000 (Fig. 1). The first ORF is incomplete and terminates at position 779. The putative translated product showed significant homology to PdxA, a pyridoxal phosphate biosynthetic protein of E. coli (Roa et al., 1989). There was $54 \%$ similarity and $32 \%$ identity over the complete translated tegion of ORF1. $p d x A$ encompasses approximately $1 \mathrm{kbp}$ DNA, producing a polypeptide of $35.1 \mathrm{kDa}$ in size (Roa et al., 1989). If ORF1 is of comparable size, then we estimate that between 200 and $300 \mathrm{bp}$ of the $5^{\prime}$ end are missing from pMOP1000.

ORF2 begins 13 bp downstream of ORF1 and there is a putative Shine-Dalgatno sequence, AGGAG, 8 bp upstream of the putative ATG start codon (Shine \& Dalgarno, 1975; Fig. 2). The predicted polypeptide is 431 amino acids in length and has a predicted molecular mass of $45.6 \mathrm{kDa}$. Predicting functionality for this protein was done by alignment with known proteins from the sequence database and the identification of motifs of known function. A BLAST analysis of the putative translated product of ORF2 revealed significant homologies to reductase proteins of both aromatic and aliphatic degradative pathways: $33 \%$ identity and $47 \%$ similarity to TodA, a reductase component of $P$. putida toluene $1,2-$ dioxygenase (Zylstra \& Gibson, 1989); $31 \%$ identity and $47 \%$ similarity to $\mathrm{BphA}$, a reductase component of biphenyl dioxygenase from Pseudomonas pseudoalcaligenes (Erickson \& Mondello, 1992); $31 \%$ identity and $45 \%$ similarity to Bed $\mathrm{A}$, the reductase component of benzene dioxygenase from $P$. putida ML 2 (Tan et al., 1993); $31 \%$ identity and $43 \%$ similarity to $\operatorname{Ter} A$, a terpredoxin reductase from Pseudomonas sp. (Peterson et al., 1992); $30 \%$ identity and $41 \%$ similarity to CamA, an NADHputidaredoxin reductase involved in camphor metabolism in P. putida (Koga et al., 1989); and 26\% identity and $38 \%$ similarity to AlkT, the rubredoxin reductase component of alkane hydroxylase from Pseudomonas oleovorans (Eggink et al., 1990). We have called ORF2 mop $A$ and refer to its putative protein product as MopA.

There are two conserved motifs which are associated with reductase proteins. The first is $\mathrm{GXGX}_{2} \mathrm{GX}_{3} A \mathrm{X}_{6} \mathrm{G}$ (where $\mathrm{X}$ is any amino acid), which forms a $\beta \alpha \beta$ fold responsible for binding the ADP moiety of FAD or NAD (Wierenga et al., 1985). The second consensus is $T \mathrm{X}_{6} \mathrm{AXGD}$, which is responsible for binding the flavin moiety of $\mathrm{FAD}$ (Eggink et al., 1990). When a Clustal $\mathrm{V}$ alignment of MopA was performed with the six reductases showing high homologies, three conserved regions were identified in MopA. The first was at the N-terminal end between amino acids 17 and 33, followed by a second region between amino acids 159 and 175 . Both these regions match the FAD and NAD consensus motif, respectively, except that an alanine replaces the third glycine in the first motif. A third motif situated between amino acids 274 and 281 matches the second consensus, known to bind the flavin moiety of FAD.

We investigated further the presence of an alanine in place of glycine in the first motif. The third conserved glycine is considered important to allow for a close interaction between the $\beta$ strands and the $\alpha$ helix (Wietenga et al., 1985). Wierenga et al. (1986) went on to propose that these three glycine residues are strictly required for NAD- or FAD-binding $\beta \alpha \beta$ units. Eggink et al. (1990) found that the second fingerprint, which binds the ribityl moiety of FAD/NAD, was an excellent predictor for FAD-binding oxidoreductases. We examined the Swiss-Prot and PIR databases for proteins which invariably retained the second fingerprint but which contained either glycine or alanine at the third position of the first motif. The analysis was carried out using the Scrutineer program (Sibbaid \& Argos, 1990). The sequence search tag initially was 
AAGCTTTCGCGTCGGGGCGCATCGTGGTGCTGGATCCGCTCGATCTTGCGCCGCACGAGTATGTCACGGGCCAGCCTTCCGCCGCGGCGGGACGAGCCGTCGTCCGCTGGATGGCGCTCG

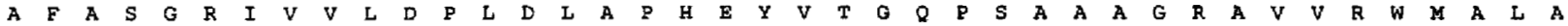
CGGACCGGATCGCGCATGACGGACTGATCGGCGGATGGATCATGGGGCCGATCGATTCGACGTCGCTCAAGCTCGCGGGGGAAGTGGCAAGCATCGACGAACTCCAGCCCGAGCATTCCT

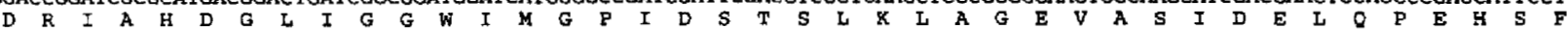
TCATGTTTCGCATGAGCGGCAGACTGCGCGTGGTGCCGTTGACGGAGCACATCCCGCTGCGCGACGTGCCCGCCACCGTGACTTTCGATGCGGTGCTCAACCTGGTCACGCTGGTCAATG

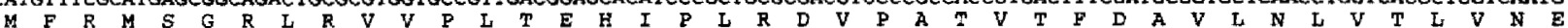
AGCGTTTGAAGGACTGGGGGATCGAGGCGCCGCGCATCGGCGTTGCGGGGCTCAACCCGCACGCCATGTTCGAGGAGGAAGAGCGAATCATCGGTCCTGCGGTCGAACAAGCCAGAGCGC

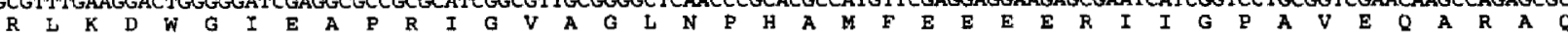
AGGGTATCGACGTGCGGGGGCCTGTTTCGCCCGACTCGGTATTTCGTCATGGACTCGACGGGCGCTATGACGCGGTCGTCAGCATGTATCACGACCAGGGGCAGATCGCACTAAAGTCGG

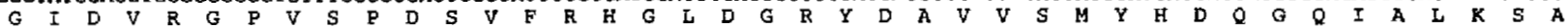
CTGCGTTCGAAGGGGCCTGCACGCTCTATCTTGGGGTGCCCTACGTGCGCGCGACCGTTCCTCACGGGACTGCAATGGGTATTGCGGGACGGAACCTGGCGCAGCATCACAGCATGGTCG

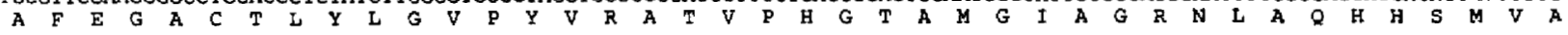
CCGCGTTGAGGACGGCGGCGGCGCTTGCCACGAAGCGCGGCTTCCT'GAACGAACAATANOARGTCGGCGGCATGGCGTACCACTCAACCAATCCGTTACTTTCACGCGTGGTGATCGTCG

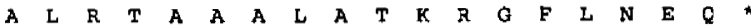

M A GAGCGGGGCAGGCCGCCGCGGCAGTGGCGAAGACCTTGCGTGCGGAGGGACATCGCGGCGAGATTATGATGCTCGGCGCTGAACGCGTGGGTCCGTATGAGCGGCCGCCCTTGTCGAAAG

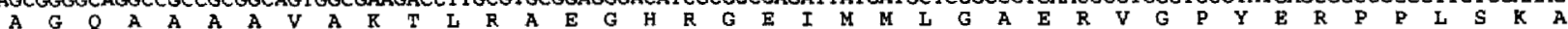
CGTGGCTGAGCGCGGAAAACGTGCCCGAAATAGCCGCTCTGCTCGAAAAGTCTGAAGCGGGGCAGTCCGATGTCGACTTGCGGACCGGGGTGAACGTTACGCGGATCGACCGCCCCTCAT W GCACCGTGCACGTCGACGATGGATCGGAGATTTGCTTCGATCGTCTCGTGATCGCAACGGGCGGACGCGCCCGGCGGCTGGCGGTGCCTGGCGACGCGAGCGACCAGATCGCCTATCTGC

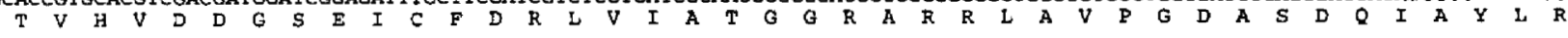
GTACGATCGACGACGCTCTGCATATCCGCCGCGGATTGAAAGCAGGCAAGCGGCTGCTGCTCATCGGGGGCOGATGGATCGGATTGGAAACCGCGTGCAGCGCCCGGAAGCTAGGCGTCG

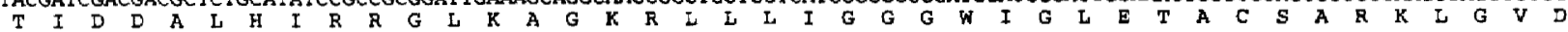
ACGTGGTGCTGGTCGAAGCGGCGCAGCGGTTATGCGAACGGACCGTCCCGGCGATCGTGGGTGAGCGTCTGCTCGGGATTCAGCGTTCGCTTGGCGTCGACGTGCGCCTTGGCGCCGGCA

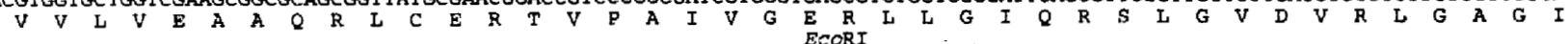
CGAGCACTGTCGAAGCTGCCCGGCGGACGTTATGCCGCTTCGCTATCGGGCGTTCGCGAAGAATTCGACCTGGTGGTTGCGGGGGTGGGCATGGTGGCGAACGACGAACTCGCGGCTG

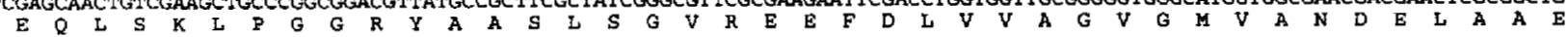
AAGCAGGTCTCCCTTGTGCGGGCGGCGTGTTATGCGACGTTGAAGGCCGCACGGTCGATCCCCACETGTTCGCGTGCGGCGATGTGGCGTCGTTCGAGCATCCTTCCGGACCCATCGGGA

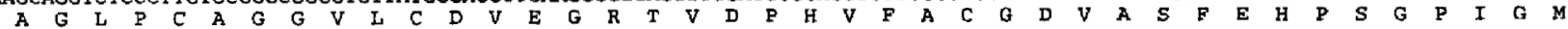
TGCGGCGGCTGGAGTCGTGGGACAACGCGCAGCAGCAGGGTGCGGCGTGTGCCCGCGCCATCCTCGGCAAGCGGGCGGCGGCGCATCCGTTGCCTTGGTTCTGGTCCGATCAGGGCGACG

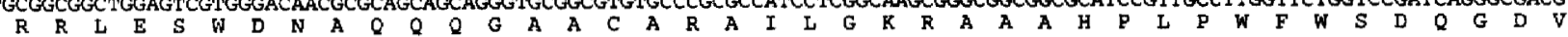
TGAATATCCAGATCCTCGGCTTCCCGAATGCGACGGCCACACCGGTCGTGCGGGAAGGCGACGGCAAGGCGACGTTGGTCTGGCTGGAGGAGCACGCAGCGGACGAGCCCGCGCAAATCG

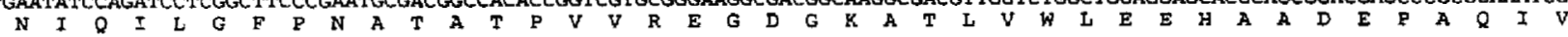
TCGCGGCGGTATGCATCAACGCGCCCGCCGACATGCCGATACTGCGCCGCATGTGGCAGAAGGGCGTGCGCGTCGACCGAAAGACGCTCGCCGTGCAGGAGGTCAGTCTCAAGAGCCTTC

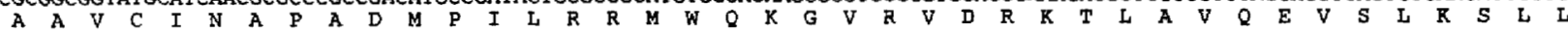
TGCAGCGTTCCGCGGGCGCCGCGAGGAATGGAGGTGCGAACACTTAGAAGCGCATCAGGCATCGGACTTTTGCATTCACATCGACAGAGCACATCAGAGCGGGCGGTACCAGTCGTGCG $Q \quad R$ S A G A A $R$ A $\quad$ G G A N T HindIII

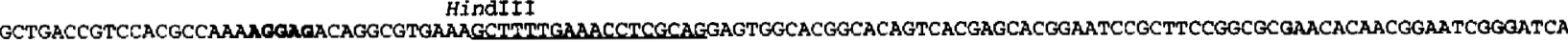

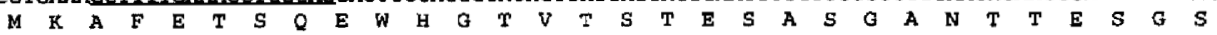
CGACGACTGTTCTTTGCCAGCTTTCTCGGCACAATGGTCGAGTGGTACGACTTTTTTCTTTACGGCTTTATCGCGCCGCTCGTTTTTGAAGAGTTGTTCTTCCCGAAGCTGAACGCACTT

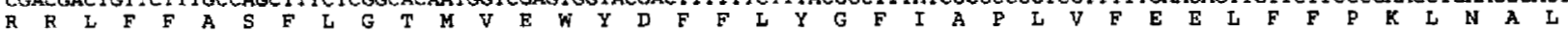
AGCGGCACCATCGCCGTGTATGCGACCTTCGCCGTTGGCTATGCGAGCCGGCCCCTCGGGGGACTCGTGTTCGGTCATTTCGGTGACAAAATCGGCCGCAAATCAATGATGCTCGTCACA

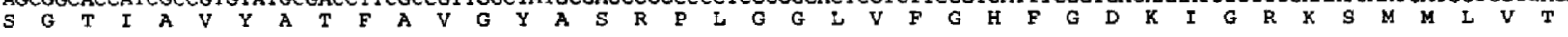
CTGCTGATGATGGGTATCGGTACTGCGECCATCGGGCTCTTGCCGAGCGTCGCGCAAATCGECATGAGCGCGACCTGTCTECTCOTCGCGCTGCGCTTCGTCCAGGGCTTCGCECTAGGG L L M M G I G Xhot GGTGAGTCGGCTGCTGCCAGCCTGATGGTGCTCGAGAGCGCGCAACAACGTCGCCGGGGCCTGCTTGGGGCAGCGCTTCAGGCGGCAGGACCGCTGGGCGTGCTGCTGGCCTCGCTGGCG

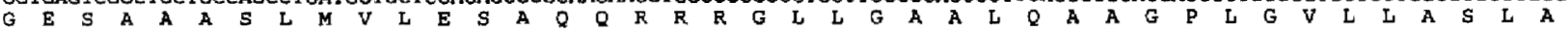
GTATTCGTCGTGTCGCGTCTGCCGCACGACGCCTTGCTTGCCTGGGGCTGGCGCGTGCCGTTCCTTGTGAGCGCCGTGCTGGTGGTGATCGGTCTGTATATCCGTTTGCGAGTCGAGGAA

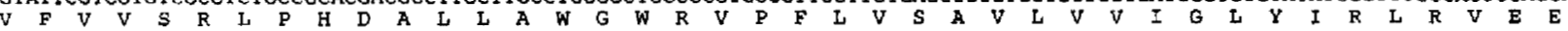
ACGGTCGCGTTCCGCAAGCAGCAGAGTAAGCACGAACTAACCCGCATCCCGGCGTGGGAAACGTTGCGCAGCTACAAGTGGCCTGTCTTCGTCGTGCTGGTAGTCAGCATTATGGAGAGC

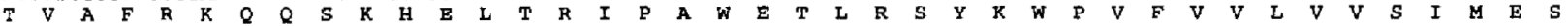
ACGTTCTACTATCTGACCGGCGTCTATTCCATCTCCTACGTCACCAAGACGCTTCATATGCCGGGGTCGGTCGCGATCGGCGCGATCGCCTGTGCTAACGCTTTTGCCCTCGTGTCGGTA

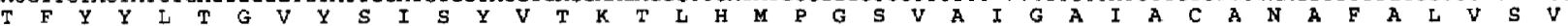
CCGCTCTATGGCGCGCTCTCCGACCGCCTCGGGCGCAAGGGCGTGTATITGCTCGGCATCGTGGCGTCGGCGATTTACCTGAACTTCTTCTTTACGATGCTCGACGGCCGTTCGGCGATG

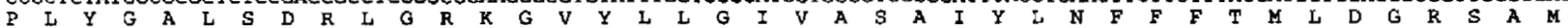
GTCGTGGTGCTCGCCGTCGTGGCAGCOGTCGGCGTGATTCATGCACCGATGTACGCCATGTTCGGCAGCTTCTATGGCGAACTGTTTCCCACGCGAGTGCGGTTCACGGGCTTCTCGATG

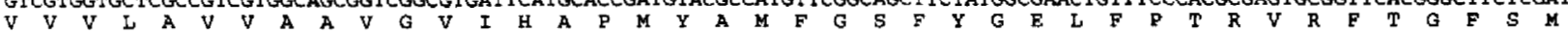
GGCAAGGCGTTCGGCACGGTGCTCGGCGGCGGCATCGCGCCGATGATCGCGGCCTCGCTCGCCGCGCGCAATCACGGAGACCCCTCCGCTATCGGTCTCTACTATCTCTGCCTCGCCTTC

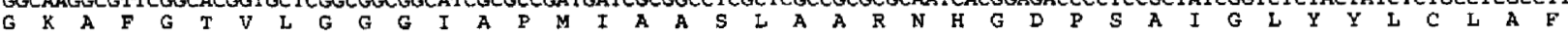
GTCGCGCTGTGCGTGGTGCTGCGCGTGCGCGAAACGCGGAACGACGACATCACCGTCTAGCAACCCTCGTTTCTCACGTAGCCATTGGACGAGCGTCGTGTGCCTCGCTGGAGGCGCACC

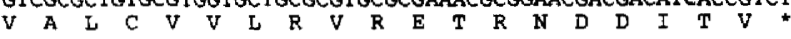

CGGCGCGGCTTTTGTTCGTCTCTCACTCTCTAAAAACATCATCATGAAGAAGAACAGGCTTCTCCTGGGCGTGCTRGCGTTCGGCGCCGGCGCCGCACACGCGGACAGCAGCGTGACGCT CTATGGCCTCATCGGTACTGGCCCCGCATACOTCAACAATGTAAAGOGCAGTCATTTGTTCGAATCCGCAAGCGGCCTGATTCAGGGPAATCGTTTCGGTTTGAAGGGGCGCGAGGATCP CGGCGGAGGCATGTCGGCCATCTTCACCCTGGAGAATGGCTTCGACGGCAACACCGGTGCGCTGGGGCAAGGCGGGCGCATGTTCGGACGGCAGGCATTCGTGGGTCTTGCCACGGAACG ATACGGCAAGCTGACCTTGOGTCGTCAGTACGATACCAATTACGATTTCATGGCGGATACGGGCGCGGCAAAACTGTTCGGCGGATGTATCCGATAACGACAACCTGTTCGGCACCGTGC

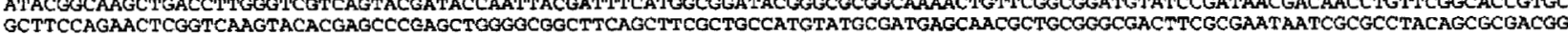
GCTTCCAGAACTCGGTCAAGTACACGAGCCC

Fig. 2. For legend see facing page. 
Table 2. Glycine substitution in the ADP-binding moiety of reductase proteins

\begin{tabular}{|c|c|c|c|c|c|c|}
\hline \multirow{2}{*}{$\begin{array}{l}\text { Organism } \\
\text { Escbericbia coli }\end{array}$} & \multirow{2}{*}{$\begin{array}{c}\text { Protein } \\
\begin{array}{c}\text { Glutathione } \\
\text { reductase }\end{array}\end{array}$} & \multicolumn{3}{|c|}{ Sequence } & \multicolumn{2}{|c|}{ Accession no./reference } \\
\hline & & 174 & GAGYIAVELAGVINGLG & 190 & GSHR_ECOLI & $\begin{array}{l}\text { Greer \& Perham } \\
(1986)\end{array}$ \\
\hline Pea & & 253 & GGGYIALEFAGIFNGLK & 269 & GSHR_PEA & \\
\hline Pseudomonas aeruginosa & & 173 & GGGYLAVEFASIFNGLG & 189 & $\mathrm{~S} 15236$ & \\
\hline Streptococcus tbermopbilus & & 174 & GAGYIAVEVAGVLNALG & 190 & $\$ 41386$ & \\
\hline Human & & 195 & GAGYIAVEMAGILSALG & 211 & S08979 & Tutic et al. (1990) \\
\hline Mouse & & 182 & GAGYIAVEIAGILSALG & 198 & & \\
\hline Sbigella flexneri & $\begin{array}{l}\text { Mercuric(II) } \\
\text { reductase }\end{array}$ & 104 & GSGGAAMAAALKAVEQG & 120 & RDEBHA & Misra et al. (1985) \\
\hline Tbiobacillus ferrooxidans & & 91 & GTGGAAMALALKAVERG & 107 & JQ0153 & Inoue et al. (1989) \\
\hline Pseudomonas aeruginosa & & 105 & GSGGAAMAAALKAVEQG & 126 & MERA_PSEAE & $\begin{array}{l}\text { Fox \& Walsh } \\
(1983)\end{array}$ \\
\hline Streptomyces lividans & & 14 & GSGAGAFAAAIAARNKG & 30 & MERA_STRLI & $\begin{array}{l}\text { Sedlmeier \& } \\
\text { Altenbuchner } \\
(1992)\end{array}$ \\
\hline Stapbylococcus aureus & & 92 & GSGGAAFSAAIKANENG & 108 & MERA_STAAU & $\begin{array}{l}\text { Laddaga et al. } \\
(1987)\end{array}$ \\
\hline Eschericbia coli & $\begin{array}{l}\text { Thioredoxin } \\
\text { reductase }\end{array}$ & 152 & GGGNTAVEEALYLSNTA & 168 & TRXL_ECOLI & $\begin{array}{l}\text { Russel \& Model } \\
(1988)\end{array}$ \\
\hline Arabidopsis thaliana & & 135 & GGGDSAMEEANFLTKYG & 151 & S44026 & \\
\hline \multirow[t]{2}{*}{ Burkbolderia cepacia Pc701 } & MopA & 17 & GAGQAAAAVAKTLRAEG & 33 & & \\
\hline & Consensus & & $G-G--G---A---\cdots--G$ & & & \\
\hline
\end{tabular}

$\mathrm{GXGX}_{2}[\mathrm{GA}] \mathrm{X}_{3} A$, and all proteins extracted wete then searched with the second consensus sequence, $\mathrm{TX}_{6} \mathrm{AXGD}$. The results are presented in Table 2 . There are clearly a variety of both prokaryotic and eukaryotic reductases which contain alanine in place of the third glycine in the ADP-binding motif. We found that the second consensus sequence by itself only extracted proteins identified or putatively identified as ferredoxins, reductases or dehydrogenases. Our analysis suggests that the second consensus is the more definitive seatch tool for the putative identification of reductase proteins.

Downstream of mopA there is another ORF which we have termed mopB. The ORF is preceded by a putative Shine-Dalgarno sequence and begins with the rare codon GTG (Fig. 2). mopB is 1347 nucleotides and encodes a predicted protein of 449 amino acids in length and $48.3 \mathrm{kDa}$ in size. Further evidence to suggest that GTG is the start codon of mop $B$ is provided by the position of the HindIII site just downstream. Previous subcloning demonstrated that the HindIII site bisects a gene functional in complementation. The predicted amino acid sequence for the protein encoded by mop $B$ shows a proportion of non-polar amino acid residues typical of integral membrane proteins $(69.5 \% \mathrm{Ala}$, Cys, Phe, Gly,
Ile, Leu, Met, Pro, Val, Trp and Tyr) (Culham et al., 1993). Using the BLAST protein alignment program, the predicted protein showed high overall identity, between 48 and $57 \%$, with several members of a superfamily of symport-type transporter proteins, including E. coli ProP, a proline betaine transporter (Culham $e$ t al., 1993), E. coli KgtP, a 2-oxoglutarate ( $\alpha$-ketoglutarate) transporter (Seol $\&$ Shatkin, 1991), and several citrate-proton symport proteins, namely Cit1 (Sasatsu et al., 1985) and Cit2 (Ishiguru \& Sato, 1985) of E. coli; CitA of Salmonella typbimurium (Shimamoto et al., 1991) and $\mathrm{CitH}$ of Klebsiella pneumoniae (van der Rest et al., 1990). Fig. 3 shows a Clustal $\mathrm{V}$ alignment of representatives of this group with MopB. Additionally, all the proteins shown were analysed using the algorithms of Kyte \& Doolittle (1982) and Kaneshisa (1982) to predict possible hydrophobic membrane-spanning domains. The analysis revealed 12 predicted highly hydrophobic membrane-spanning regions, shown in Fig. 3. The regions were in good agreement with those previously predicted for these proteins. Cit $A$ has been found to be a member of a membrane transporter gene superfamily that includes a number of eukaryotic transporter proteins (Maiden $e t$ al., 1987). Seol \& Shatkin (1991) aligned KgtP with Cit A, E. coli A raE and the human hepatoma glucose carrier (Glu). They

Fig. 2. Nucleotide sequence and predicted translation products of the pMOP1000 insert. Some restriction sites are shown for ease of orientation with regard to the data presented in Fig. 1. Putative Shine-Dalgarno sequences are shown in bold type whilst the positions of primers used for primer extension analysis are underlined. Arrows indicate the positions of inverted repeat sequences which may form a transcription termination signal. 


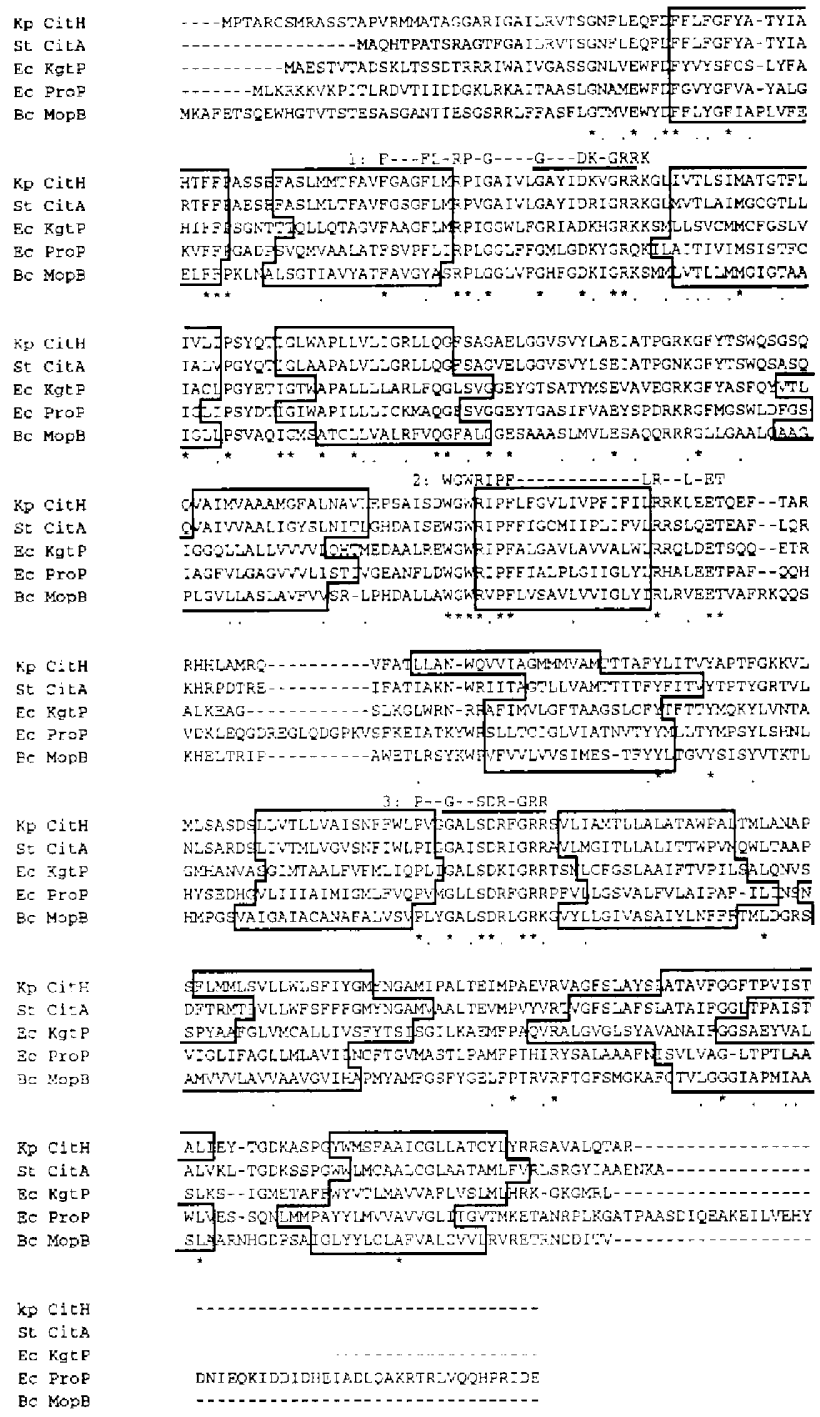

Fig. 3. Alignment of MopB with members of a family of bacterial symport proteins. Asterisks indicate identities across all proteins and dots indicate conservative substitutions. Boxed amino acids are those predicted to form hydrophobic transmembrane domains. Motifs which are typical of this class of proteins are indicated. 1, 2 and 3 are motifs described by Culham et al. (1993). The duplicated motif described by Jessen. Marshall et al. (1995) is shown underlined within motifs 1 and 3. $\mathrm{Kp} \mathrm{CitH}, K$. pneumonize citrate permease; St CitA, $S$. typhimurium citrate permease; EC KgtP, E. coli 2-oxoglutarate (x-ketoglutarate) permease; Ec ProP, E. coli proline permease; Bc MopB, B. cepacia 4-methylphthalate permease.

identified a duplicated motif ( $R / K) X G R(R / K)$ common to these proteins which is also present in MopB (Fig. 3). Culham et al. (1993), in their analysis of ProP, defined three conserved sequence motifs. Two of these include the duplicated motif whilst another bridges the sixth hydrophobic domain (Fig. 3). MopB shows $79 \%$ identity and $97 \%$ similarity of amino acid residues over these conserved regions, with only a single amino acid difference in region 1. Recently, a precise study of LacY of $E$. coli further defined the duplicated motif as
$\mathrm{GX}_{3}(\mathrm{D} / \mathrm{E})(\mathrm{R} / \mathrm{K}) \mathrm{XG}(\mathrm{R} / \mathrm{K})(\mathrm{R} / \mathrm{K})$, which is common to a wide variety of both eukaryotic and prokaryotic permeases, including MopB (Jessen-Marshall et al., 1995) (Fig. 3).

Jung et al. (1995) recently presented some studies on LacY which provided insight into the structure of this class of permeases. They replaced glycine residues at various positions in LacY and monitored the effects on activity. There were three giycine residues which, when replaced by cysteine, completely inactivated the protein, at positions 64,115 and 147 , respectively. However, when Gly was replaced by Ala at these positions, activity was restored to almost wild-type levels. LacY shows a low overall level of homology to $\mathrm{MopB}$, but contains both copies of the short $(\mathrm{R} / \mathrm{K}) \mathrm{XGR}(\mathrm{R} / \mathrm{K})$ consensus proposed by Seol \& Shatkin (1991), between hydrophobic domains 2 and 3 and 8 and 9 , and a single copy of the $\mathrm{GX}_{3}(\mathrm{D} / \mathrm{E})(\mathrm{R} / \mathrm{K}) \mathrm{XG}(\mathrm{R} / \mathrm{K})(\mathrm{R} / \mathrm{K})$ motif proposed by Jessen-Marshall et al. (1995) between hydrophobic domains 2 and 3. Alignment of LacY with MopB (data not presented) revealed that $\mathrm{Gly}_{64}$ of LacY corresponds to $\mathrm{Gly}_{95}$ of MopB, which is the first Gly of the $\mathrm{GX}_{3}(\mathrm{D} / \mathrm{E})(\mathrm{R} / \mathrm{K}) \mathrm{XG}(\mathrm{R} / \mathrm{K})(\mathrm{R} / \mathrm{K})$ consensus between hydrophobic domains 2 and 3 (Fig. 3). Gly $y_{115}$ corresponds to Gly $_{146}$ of MopB found in the fourth hydrophobic domain, which is also present in the four other proteins aligned in Fig. 3. However, Gly ${ }_{147}$ corresponds to $\mathrm{Ala}_{179}$ in MopB, and is represented by Thr and Ser, as well as Gly, in the four other permeases in Fig. 3. In a detailed study of the $\mathrm{GX}_{3}(\mathrm{D} / \mathrm{E})(\mathrm{R} / \mathrm{K}) \mathrm{XG}(\mathrm{R} / \mathrm{K})$ motif, JessenMarshall et al. (1995) produced a variety of site-directed mutations at the first, fifth, sixth, eighth, ninth and tenth positions in LacY. They found that an amino acid with a bulky side chain at position 1, equivalent to $\mathrm{Gly}_{64}$ in the Jung et al. (1995) study, caused inactivation. The acidic amino acid at position five was critical and could not be replaced; this is retained as aspartate in all the proteins analysed in Fig. 3. They suggested that since this motif is conserved among proteins that transport a wide range of solutes, it is unlikely to be concerned with solute binding. The identification of MopB and its retention of the consensus would tend to support this theory.

\section{mopA and mopB are cotranscribed}

We conducted a detailed search of the DNA sequence presented here for possible $-12 /-24-$ and $-10 /-35-$ like promoter sequences which might be present, but there were nonc apparent. However, we could not rule out the possibility that there might be a sequence upstream of mop $A$ or mop $B$ capable of being recognized as a promoter in B. cepacia. Two primers were designed and primer extension experiments were performed to distinguish this possibility. The two primers are indicated in Fig. 2, and are positioned just downstream of the putative start codons of mop $A$ and $m o p B$. No primer extension product was seen with either oligonucleotide (data not presented). Total RNA was extracted from mid-exponential-phase cells of B. cepacia Pc701 grown on succinate or 4-methylphthalate, electrophoresed and Northern blot 
(a)

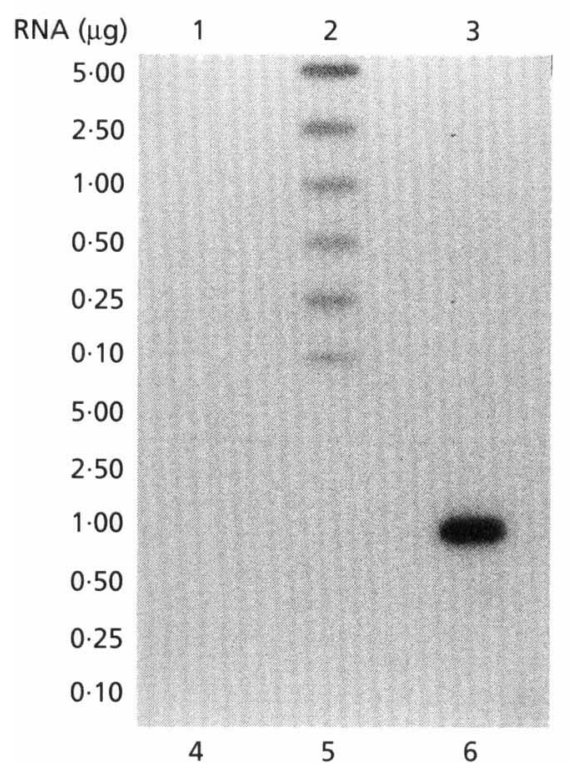

(b)

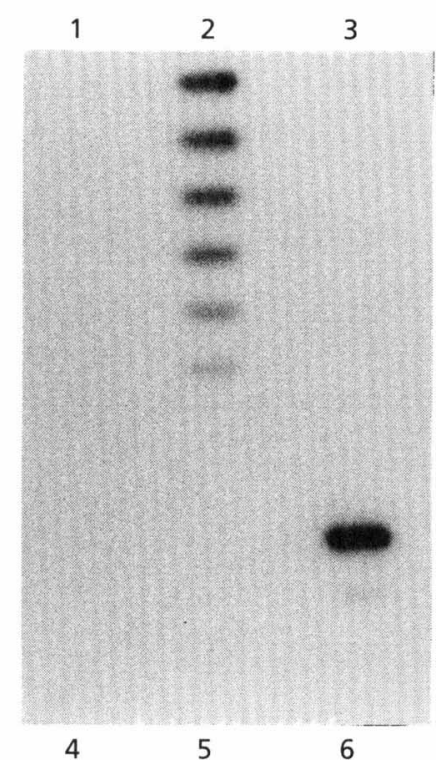

Fig. 4. Northern hybridization analysis of total RNA extracted from B. cepacia Pc701 employing mopA and mopB probes. DNA probes were hybridized to total RNA extracted from cells grown on a range of substrates. Total amounts of RNA used $(\mu \mathrm{g})$ are indicated. (a) mopB probe; (b) mopA probe. Lanes $1-5$ in each experiment contained the same RNAs, prepared from cells grown on the following substrates: 1 , succinate; 2, 4-methylphthalate; 3 . phthalate; 4, 4-hydroxyisophthalate; 5, benzoate. Positive controls were employed for each probe: single slots contained $0.1 \mu \mathrm{g}$ pMOP1220 in lane 6 of (a) and $0.1 \mu \mathrm{g}$ pMOP1120 in lane 6 of (b). analysis was performed using DIG-labelled mop $A$ and mop $B$ internal probes. We saw hybridization with both probes, but only to RNA extracted from 4-methylphthalate-grown cells. However, partial degradation of RNA was always seen for repeat isolations and aiso using an alternative extraction procedure. The resulting smeared band had a maximum size of about $10 \mathrm{kbp}$, suggesting that a single long transcript was produced which was difficult to extract in its entirety. Sequence analysis revealed a possible rho-independent transcription termination signal downstream of mopB (Fig. 2). The structure had a calculated $\Delta G$ of $-18 \mathrm{kcal} \mathrm{mol}^{-1}$ $\left(-75 \mathrm{~kJ} \mathrm{~mol}^{-1}\right.$ ) (Tinoco et al., 1973).

Induction of the transcript encoding MopA and MopB with a range of substrates was investigated. B. cepacia Pc701 readily grows in medium containing phthalate or benzoate. Total RNA was extracted from ceils grown to mid-exponential phase on these substrates or succinate, 4methylphthalate or 4-hydroxyisophthalate. Slot blot analysis was performed using between 5 and $0 \cdot 1 \mu \mathrm{g}$ of total RNA and identical probes to mop $A$ and $m o p B$ used in the large-scale Northern blot experiments. Fig. 4 shows the resultant autoradiograph. Only hybridization with RN $\Lambda$ extracted from 4-methylphthalate-grown cells was seen, and was visible down to the $0.1 \mu \mathrm{g}$ level. Interestingly, although phthalate is a substrate for MopB, it does not bring about induction of the MOP transcript, suggesting regulation is tightly controlled.

B. cepacia Pc701 degrades 4-methylphthalate via a diol intermediate which is dehydrogenated to give 2,3dihydroxy-p-toluate; this is subsequently cleaved by an extradiol dioxygenase reaction (Anderson, 1980; Saint, 1986). Subsequent products are substrates for the tricarboxylic acid pathway. The initial conversion of 4methylphthalate to its respective diol is a reaction type usually associated with multicomponent dioxygenases incorporating a reductase component (Harayama et al., 1992). Sequence analysis combined with transcriptional studies suggest that MopA is a reductase directly associated with 4-methylphthalate degradation. Previously, multicomponent dioxygenases have been found to consist of discrete genetic units with tandemly arranged components (van der Meer et al., 1992). Whilst mopA may form part of the same transcriptional unit as the other essential dioxygenase components, there is clearly a locational separation.

\section{MopB is a phthalate-specific permease}

To facilitate functional studies on MopB, a $3.5 \mathrm{kbp}$ BamHI-EcoRI fragment of pMOP1420 was cloned into pKK233-3 downstream of the $\mathrm{P}_{\text {tac }}$ promoter. With respect to pMOP1000 (Fig. 1), the fragment contained all pMOP-derived DNA to the right of the EcoRI site and a small section $(0.7 \mathrm{kbp})$ of pKT230 up to the vectorencoded $B a m \mathrm{HI}$ site. This includes the complete $\operatorname{mop} B$ ORF, but only the $3^{\prime}$ region of mop $A$. Directional cloning into pKK233-3 resulted in transcription proceeding from $\mathrm{P}_{t a c}$ towards mopB. Sequence and primer extension analysis confirmed that there was no functional promoter upstream of mopB; therefore we expected pMOP1430 to contain mop $B$ under the regulatory control of $\mathrm{P}_{t a c}$. Lptake assays were performed in $E$. coli transformed with pMOP1430. The host was grown on a supplemented minimal medium with succinate as carbon and energy source. Late-exponential-phase cells were harvested and resuspended in minimal medium containing succinate and either 4-methylphthalate, 4-hydroxyisophthalate, phthalate, benzoate or $p$-toluate. After incubation for $1 \mathrm{~h}$, the non-metabolizable inducer of $P_{t a c}$, IPTG, was added and supernatant samples were removed every $10 \mathrm{~min}$ and 
(a)

(b)

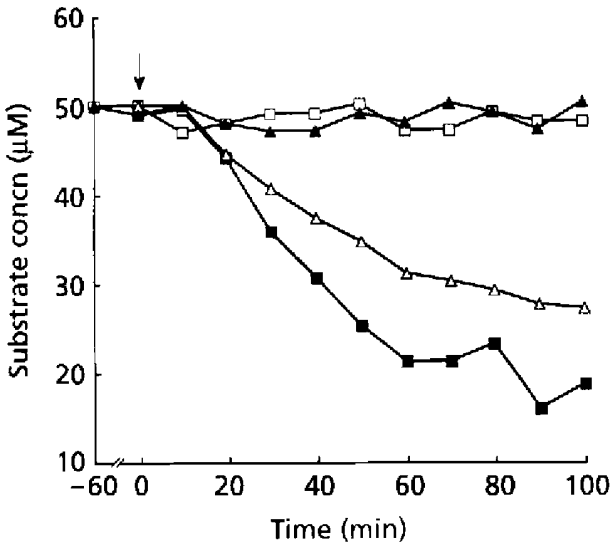<smiles>Cc1ccc(C(=O)O)c(C(=O)O)c1</smiles>

(e)

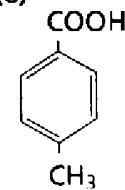

Fig. 5. Aromatic uptake by E. coli JM105 (pMOP1430). Full details of the assay technique are given in Methods. A summary of the aromatics tested along with their uptake profiles are presented: (a) 4methylphthalate; (b) 4-hydroxyisophthalate; (c) phthalate; (d) benzoate; (e) p-toluate. For clarity, only data for phthalate and 4methylphthalate are presented graphically, as the patterns for all other substrates were identical to the negative control, $E$. coli JM105(pKK233-3). ם, JM105(pMOP1430)+4methylphthalate; $\square, J M 105($ pKK233-3) +4methylphthalate; $\triangle$, JM105(pMOP1430)+ phthalate; $\mathbf{A}$, JM105(pKK233-3) + phthalate. scanned spectrophotometrically for aromatic substrate removal. Only 4-methylphthalate and phthalate were seen to be removed from the medium. Fig. 5 shows the pattern of removal up to and following the addition of IPTG. There was no removal of any substrate from medium containing E. coli(pKK233-3), and a similar pattern was seen for media containing 4-hydroxyisophthalate, benzoate and p-toluate when incubated with induced $E$. coli(pMOP1430). For simplicity, these data have been omitted from Fig. 5. There was both a faster and greater removal of 4-methylphthalate than phthalate, but both substrates did not continue to be removed beyond $100 \mathrm{~min}$. These studies suggested that the presence of two ortho-placed carboxyl groups is critical for permease recognition.

The methodology developed for functional studies on MopB should be applicable to other bacterial uptake systems. The technique is particularly useful where the expense or lack of availability of radiolabelled substrates makes comprehensive uptake studies impossible. The combination of a high level of induction coupled with high cell numbers in the assay was sufficient to permit detection of substrate removal from the supernatant. We never detected the appearance of new absorption peaks when scanning culture media, further suggesting that MopB actively removes substrate and does not merely convert phthalate or 4-methylphthalate to their respective dihydrodiols, which might be expected to accumulate in the culture medium. Removal stopped abruptly with both phthalate and 4-methylphthalate. Possibly destabilization of the cell membrane due to permease overproduction, the toxicity of substrate build-up in the cells, or the dissolution of the energy gradient required for uptake could explain this. We never saw substrate levels subsequently rise in the supernatant or monitored a decrease in optical density of the cell suspension, suggesting that cells remained intact.
The identification of $\mathrm{MopB}$ as a permease involved in aromatic uptake is of significance. Previous genetic and biochemical analysis of aromatic degradative pathways in bacteria have not revealed the presence of specific transport mechanisms. Cloning and sequencing of mop $B$ should allow the design of probes to search for other aromatic permeases in closely related genera.

\section{ACKNOWLEDGEMENTS}

The authors wish to express their gratitude to Dr $\mathrm{N}$. C. McClure for his critical appraisal of the manuscript.

\section{REFERENCES}

Altschul, S. F., Gish, W., Miller, W., Myers, E. W. \& Lipman, D. J. (1990). Basic local alignment scatch tool. J Mol Biol 215, 403-410.

Anderson, B. N. (1980). 4-Methyiphtisalic atid utilization by soit pseudomonads: biocbemistry and genetics of plasmid encoded functions. $\mathrm{PhD}$ thesis, University of Miami, USA.

Autian، J. (1973). Toxicity and health threats of phrhalate esters: review of the literature. Environ Health Perspect 4, 3-26.

Bagdasarian, M., Lurz, R., Rukert, B., Franklin, F. C. H., Bagdasarian, M. M., Frey, J. \& Timmis، K. N. (1981). Specific purpose plasmid cloning vectors. II. Broad host range, high copy number, RSF1010 derived vectors, and a host vector system for gene cloning in Pseudomonas. Gene 16, 237-247.

Brosius, J. \& Holy, A. (1984). Regulation of ribosomal RNA promoters with a synthetic lac operator. Proc Natl Acad $S_{c i} U S A$ 81, 6929-6933.

Culham, D. E., Lasby, B., Marangoni, A. G., Milner, J. L., Steers, B. A., van Nues, R. W. \& Wood, J. M. (1993). Isolation and sequencing of Escherichia coli gene proP reveals unusual structural features of the osmoregulatory proline/betaine transporter, ProP. J Mol Biol 229, 268276.

Ditta, G., Schmidhauser, T., Yakobson, E., Lu, P., Liang, X. P., Finlay, D. R., Guiney, D. \& Helinski, D. R. (1985). Plasmids related to the broad host range vector, pRK290, useful for gene cloning and for monitoring gene expression. Plasmid 13, 149-153. 
Dutton, J. R., Venables, W. A. \& Saint, C. P. (1995). Comamonas acidovorans UCC61 catabolizes o-phthalate via a 4,5-oxygenation pathway that is encoded on a $70 \mathrm{kbp}$ section of plasmid $\mathrm{pOPH} 1$ bounded by directly repeated sequences. Microbialogy 141, 16731682.

Eaton, R.W. \& Ribbons, D. W. (1982). Metabolism of dibutylphthalate and phthalate by Micrococtus sp. strain 12B.J Bacteriol 151, $48-57$.

Eggink, G., Engel, H., Vriend, G., Terpstra, P. \& Witholt, B. (1990). Rubredoxin reductase of Psetdomonas oleovorans; structural relationship to orher flavoprotein oxidoreductases based on one NAD and two FAD fingerprints. $J$ Mol Biol 212, 135-142.

Erickson, B. D. \& Mondello, F. J. (1992). Nucleotide sequencing and transcriptional mapping of the genes encoding biphenyl dioxygenase, a multicomponent polychlorinated-biphenyl-degrading enzyme in Pseudomonas strain LB400. J Bacteriol 174, 2903-2912.

Figurski, D. H. \& Helinski, D. R. (1979). Replication of an origin containing derivative of RK2 dependent on a plasmid function in trans. Proc Natl Acad Si USA 76, 1648-1652.

Fox, B. S. \& Walsh, C. T. (1983). Mercuric reductase: homology to glutathione reductase and lipoamide dehydrogenasc. Iodoacetamide alkylation and sequence of the active site peptide. Biocbemistry 22, 4082-4088.

Greer, S. \& Perham, R. N. (1986). Glutathione reductase from Escherichia coli: cloning and sequence analysis of the gene and relationship to other flavoprotein oxidoreductases. Biochemistry $\mathbf{2 5}$, $2736-2742$.

Grinter, N. J. (1983). A broad host range cloning vector transposable to various replicons. Gene 21, 133-143.

Harayama, S., Kok, M. \& Neidle, E. L. (1992). Functional and evolutionary relationships among diverse oxygenases. Annu Rev Microbiol 46, 565-601.

Inoue, C., Sugawara, K., Shiratori, T., Kusano, T. \& Kitagawa, Y. (1989). Nucleotide sequence of the Thiobacillus ferrooxidans chromosomal gene encoding mercuric reductase. Gene 84, 47-54.

Ishiguru, N. \& Sato, G. (1985). Nucleotide sequence of the gene determining plasmid-mediated citrate utilization. I Bacteriol 164, 977-982.

Jessen-Marshall, A. E., Paul, N. J. \& Brooker, R. J. (1995). The conserved motif, $\mathrm{GXXX}(\mathrm{D} / \mathrm{E})(\mathrm{R} / \mathrm{K}) \mathrm{XG}[\mathrm{X}](\mathrm{R} / \mathrm{K})(\mathrm{R} / \mathrm{K})$, in hydrophilic loop $2 / 3$ of the lactose permease, $J$ Biol Chem 270 , 16251-16257.

Jung, K., Jung, H., Colacurcio, P. \& Kaback, H. R. (1995). Role of glycine residues in the structure and function of lactose permease, an Escherichia coli membrane transport protein. Biocbemistry 34, 1030-1039.

Kaneshisa, M. (1982). Los Alamos sequence analysis package for nucleic acids and proteins. Nucleic Acids Res 10, 183-196.

Keith, L. H. \& Telliard, W. A. (1979). Priority pollutants; I-A perspective view. Enwiron $S_{t i}$ Tecbnol 13, 416-423.

Koga, H., Yamaguchi, E., Matsunaga, K., Aramaki, H. \& Horiuchi, T. (1989). Cloning and nucleotide sequences of NADH-putidairedoxin reductase gene $(\mathrm{cam} A)$ and putidaredoxin gene $(\mathrm{cam} B)$ involved in cytochrome P-450cam hydroxylase of Pseudomonas putida. J Biochem 106, 831-836.

Kyte, J. \& Doolittle, R. F. (1982). A simple method for displaying the hydropathic nature of a protein. J Mol Biol 157, 105-132.

Laddaga, R. A., Chu, L., Misra, T. K. \& Silver, S. (1987). Nucleotide sequence and expression of the mercurial-resistance operon from Staphylococous aureus plasmid p1258. Proc NatI Acad Sici US A 84, 5106-5110.
Maiden, M. C. J., Davis, E. O., Baldwin, S. A., Moore, D. C. M. \& Henderson, F. J. F. (1987). Mammalian and bacterial sugar transport proteins are homologous. Nature 325, 641-643.

van der Meer, J. R., de Vos, W. M., Harayama, S. \& Zehnder, A. J. B. (1992). Molecular mechanisms of genetic adaptation to xenobiotic compounds. Microbiol Rew 56, 677-694.

Misra, T. K., Brown, N. L., Haberstroh, L., Schmidt, A., Goddette, D. \& Silver, S. (1985). Mercuric reductase structural genes from plasmid R100 and transposon Tn501: functional domains of the enzyme. Gene 34, 253-262.

Nakazawa, T. \& Hayashi, E. (1977). Phthalate metabolism in Pseudomonas testasteroni: accumulation of 4,5-dihydroxyphthalate by a mutant strain. J Bacteriol 131, 42-48.

Nomura, Y., Takada, N. \& Oshima, Y. (1990). Isolation and identification of phthalate-utilizing bacteria. J Ferment Bioeng 67, 297-299.

Peakall, D. B. (1975). Phthalate esters; occurrence and biological cffects. Residue Rev 54, 1-41.

Peterson, J. A., Lu, J.-Y., Geisselsoder, J., Graham-Lorence, S., Carmona, C., Witney, F. \& Lorence, M. C. (1992). Cytochrome P$450_{\text {terp }}$ : isolation and purification of the protein and cloning and sequencing of its operon. J Biol Chem 267, 14193-14203.

Pujar, B. G. \& Ribbons, D. W. (1985). Phthalate metabolism in Pseudomonas fluorescens PHK: purification and properties of 4,5dihydroxyphthalate carboxylase. Appi Entiran Microbiol 49, 374 376.

van der Rest, M. E., Schwarz, E., Oesterhelt, D. \& Konings, W. N. (1990). DNA sequence of a citrate carrier of Klebsiella pnetumoniae. Ear J Biochem 189, 401-407.

Roa, B. B., Connolly, D. M. \& Winkler, M. E. (1989). Overlap between $p d x A$ and $\operatorname{ksg} A$ in the complex $p d x A-k s g-A-a p a G-a p a H$ operon of Escberichia coli K-12. J Bacteriol 171, 4767-4777.

Russel, M. \& Model, P. (1988). Sequence of thioredoxin reductase from Escberichia coli. J Biol Cben 263, 9015-9019.

Saint, C. P. (1986). Genetics and biocbemistry of catabolic plasmids in Pseudomonas. $\mathrm{PhD}$ thesis, University of Wales, UK.

Saint, C. P. \& Ribbons، D. W. (1990). A catabolic plasmid involved in 4-methyl-o-phthalate and 4-hydroxy-iso-phthalate degradation in Pseudomonas cepacia. FEMS Microbiol Lett 69, 323-328.

Saint, C. P., McClure, N. C. \& Venables, W. A. (1990). Physical map of the aromatic amine and $m$-toluate catabolic plasmid pTDN1 in Pseudomanas putida: location of a unique meta-cleavage pathway. I Gen Microbiol 136, 615-625.

Sambrook, J., Fritsch, E. F. \& Maniatis, T. (1989). Molecular Cloning: a Laboratory Manual, 2nd edn. Cold Spring Harbor, NY: Cold Spring Harbor Laboratory.

Sasatsu, M., Misra, T. K., Chu, L., Laddaga, R. \& Silver, S. (1985). Cloning and DNA sequence of a plasmid determined citrate utilization system in Escherichia coli. J Bacteriol 164, 983-993.

Sedlmeier, R. \& Altenbuchner, J. (1992). Cloning and DNA sequence analysis of the mercury resistance genes of Streptomyces liwidans. Mol Gen Genet 236, 76-85.

Seol, W. \& Shatkin, A. J. (1991). Escberichia coli kgtP encodes an $\alpha-$ ketoglutarate transporter. Proi Nati Acad Sci US A 88, 3802-3806.

Shimamoto, T., Izawa, H.s Daimon, H., Ishiguro, N., Shinagawa, M., Sakano, Y., Tsuda, M. \& Tsuchiya, T. (1991). Cloning and nucleotide sequence of the gene (cit $A$ ) encoding a citrate carrier from Salmonella typimurium. J Biochem 110, 22-28.

Shine, J. \& Dalgarno, L. (1975). Determinant of cistron specificity in bacterial ribosomes. Nature 254, 34-38. 
Sibbald, P. R. \& Argos, P. (1990). Scrutineer: a computer program which flexibly seeks and describes motifs and profiles in protein sequence databases. Comput Appl Biosci 6, 279-288.

Tan, H.-M., Tang, H.-Y., Joannou, C. L., Abdel-Wahab, N. H. \& Mason, J. R. (1993). The Pseudomonas putida ML2 plasmid-encoded genes for benzene dioxygenase are unusual in codon usage and low in $G+C$ content. Gene 130, 33-39.

Tinoco, L., Borer, P. N., Dengler, B., Levine, M. D., Uhlenbeck, O. C., Crothers, D. M. \& Gralla, J. (1973). Improved estimation of secondary structure in ribonucleic acids. Nature 246, $40-41$.

Tutic, M., Lu, X., Schirmer, R. H. \& Werner, D. (1990). Cloning and sequencing of mammalian glutathione reductase cDNA. Eur $J$ Biochem 188, 523-528.

Wang, R. F. \& Kushner, S. R. (1991). Construction of versatile low copy number vectors for cloning, sequencing and gene expression in E. coli. Gene 100, 195-199.
Wierenga, R. K., De Maeyer, C. H. \& Hol, W. G. J. (1985). Interaction of pyrophosphate moieties with $\alpha$-helices in dinucleotide binding proteins. Biocbemistry 24, 1346-1357.

Wierenga, R. K., Terpstra, P. \& Hol, W. G. J. (1986). Prediction of the occurrence of the ADP-binding $\beta x \beta$-fold in proteins, using an amino acid sequence fingerprint. J Mol Biol 187, 101-107.

Yanisch-Perron, C., Vieira, J. \& Messing, J. (1985). Improved M13 phage cloning vectors and host strains: nucleotide sequences of the M13mp18 and pUC19 vectors. Gene 33, 103-119.

Zylstra, G. J. \& Gibson, D.T. (1989). Toluene degradation by Psetudomonas putida F1 nucleotide sequence of the $\operatorname{tadC1C2BADE}$ genes and their expression in Escbericbia coli. J Biol Cbem 264 14940-14946.

Received 22 February 1996; revised 15 April 1996; accepted 22 April 1996. 